\title{
EKSPLANASI PENGOBATAN ALTERNATIF SUPRANATURAL BERDASARKAN TINJAUAN TEORI GELOMBANG OTAK DAN HIPNOSIS
}

\author{
Sunardi ${ }^{1}$, Sujito ${ }^{2}$ \\ ${ }^{1}$ Program Studi Doktor Pendidikan IPA Universitas Pendidikan Indonesia \\ ${ }^{2}$ Pendidikan Fisika Universitas Negeri Malang \\ Email: sunardi@upi.edu
}

\begin{abstract}
Abstrak
Penyembuhan supernatural adalah penyembuhan yang berhubungan dengan hal-hal gaib dan mistis. Ini umumnya tidak rasional. Prevalensi penyembuhan supernatural dalam kehidupan sehari-hari, disebabkan oleh persepsi orang bahwa jenis penyembuhan ini dapat memberikan efek penyembuhan yang lebih cepat dan lebih mudah dibandingkan dengan perawatan medis. Artikel ini disintesis melalui penelitian perpustakaan yang mempelajari buku, artikel ilmiah, dan referensi yang relevan karena penyembuhan alami, gelombang otak, dan hipnosis. Buku ini dirancang untuk memberikan penjelasan tentang penyembuhan supernatural berdasarkan teori gelombang otak dan hipnosis. Hasil menunjukkan bahwa metode penyembuhan supernatural dapat dilihat sebagai metode hipnosis atau hipnoterapi, di mana pemulihan pasien ditentukan oleh kemampuan paranormal untuk menjelajahi pikiran bawah sadar pasien dan untuk membawa pikiran pasien ke kondisi hipnosis tertentu, sehingga dia dapat menerima saran penyembuhan tertentu. Penjelasan penyembuhan supernatural sebagai metode hipnosis atau hipnoterapi membuat mekanisme penyembuhan supernatural dapat dijelaskan lebih rasional dan mematuhi kriteria penjelasan deduktif-nomologis penjelasan (model DN). Ini karena pengetahuan tentang hipnosis dapat dijelaskan secara deduktif melalui konsep fisika, kimia, dan biologi. Selain itu, bukti empiris tentang penggunaan hipnosis dalam kehidupan sehari-hari membuat hipnosis mematuhi teori pragmatisme.
\end{abstract}

Kata-kata Kunci : Penyembuhan Supernatural, Gelombang Otak, Hipnosis, Hipnoterapi

\begin{abstract}
Supernatural healing is the healing that deals with occultic and mystical things. It is generally irrational. The prevalence of supernatural healing in daily life, is caused by the people perception that this type of healing can provide healing effects that are faster and easier compared to medical treatment. This article was synthesized through library researchstudying books, scientific articles, and relevant references due tosupernatural healing, brainwaves, and hypnosis. It was designed to provide an explanation of supernatural healing based on the theories of brainwaves and hypnosis. The resultsshow thatthe method of supernatural healing can be seen as a hypnosis method or hypnotherapy, in wich the patient's recovery is determined by the paranormal ability to explore the subconscious mind of the patient and to bring the patient's mind to a certain hypnosis condition, so that he/she can accept certain healing suggestions. Explanation of supernatural healing as the method of hypnosis or hypnotherapy makes the supernatural healing mechanism can be explained more rationally and obeys the deductive-nomological explanation criteria ( $D-N$ model). This is because the knowledge of hypnosis can be explained deductively through concepts of physics, chemistry, and biology. In addition, empirical evidence of the use of hypnosis in everyday life makes hypnosis obey the theory of pragmatism.
\end{abstract}

Keywords : Supernatural Healing, Brainwave, Hypnosis, Hypnotherapy 


\section{Pendahuluan}

Fenomena pengobatan medis yang cukup mahal seringkali menggiring masyarakat untuk memilih jalan alternatif untuk berobat yang lebih singkat. Salah satu metode pengobatan alternatif yang cukup digemari oleh masyarakat adalah pengobatan alternatif supranatural yang dilakukan oleh dukun atau paranormal. Menurut Syamsuddin (2016) Berobat dengan cara supranatural biasanya berkaitan dengan hal ghaib dan biasanya mudah menyeret masyarakat awam kepada hal yang mistik. Hampir semua dukun dan paranormal mengatasnamakan agama, dengan menekankan pada yang berobat bahwa yang memberi kesembuhan hanyalah Allah. Model seperti ini tidak dilakukan oleh dokter. Menurut Hidayatullah (2010), praktik pengobatan supranatural dilakukan oleh seorang dukun atau paranormal yang dianggap mempunyai kekuatan atau kelebihan dari Tuhan yang tidak dimiliki orang lain, bertujuan dan memposisikan dirinya sebagai penolong. Praktik pengobatan supranatural seringkali dihubungkan dengan hal-hal gaib dan mistis, sehingga kesembuhan yang diperoleh melalui pengobatan ini tidak rasional. Menurut Fanani (2014) Metode pengobatan alternatif yang masyarakat gunakan dalam pengobatan alternatif terkadang memang sangat tidak logis karena sangat tidak sesuai dengan konsep pengobatan modern, seperti penggunaan media hewan untuk transfer penyakit, penggunaan kekuatan supranatural, air doa dan lain-lain.

Otak manusia akan menerima pesan dan informasi yang datang sesuai dengan frekuensi gelombang otak. Penjelasan sederhananya, gelombang otak diibaratkan sebagai radio atau televisi. Prinsip dasar dari kedua alat elektronik tersebut yaitu adanya saluran atau sinyal yang dapat menghantarkan pesan melalui gelombang (Muhammad, 2011). Menurut Nurul Fatma (2017) Menyebutkan bahwa otak setiap saat menghasilkan impuls-impuls listrik. Aliran listrik ini, yang lebih dikenal sebagai gelombang otak, dengan dua cara yaitu amplitudo dan frekuensi. Amplitudo adalah besarnya daya impuls listrik yang diukur dalam satuan micro volt. Frekuensi adalah kecepatan emisi listrik yang diukur dalam cycle per detik atau hertz.

Teori gelombang otak (brainwave) dan pengetahuan tentang hipnosis sangat mungkin digunakan untuk menjelaskan mekanisme pengobatan supranatural. Oleh karena itu, artikel ini berupaya memberikan eksplanasi analogis terhadap praktik pengobatan alternatif supranatural berdasarkan teori gelombang otak dan hipnosis.

\section{Metode}

Metode yang digunakan untuk menyusun artikel adalah studi kepustakaan (library research), yaitu melalui penelaahan terhadap buku-buku, artikel-artikel ilmiah, dan referensireferensi yang relevan terkait pengobatan alternatif supranatural, gelombang otak, dan hipnosis. Selain itu, hasil-hasil penelitian terkait ketiganya digunakan sebagai data pendukung yang kemudian disintesis sedemikian rupa, sehingga dapat memberikan informasi yang lebih bermakna.

\section{Hasil dan Pembahasan}

\section{Pengobatan Alternatif Supranatural}

Metode pengobatan yang selama ini dikenal di Indonesia menggunakan dua pendekatan, yaitu pengobatan medis dan pengobatan non medis atau pengobatan alternatif. Salah satu jenis pengobatan alternatif yang marak dan digemari masyarakat adalah pengobatan alternatif yang dilakukan oleh paranormal. Metode pengobatan alternatif yang dilakukan oleh paranormal ini menggunakan media-media yang kadang dinilai tidak rasional jika dihubungkan dengan penyakit yang diderita pasien(Prasetya, 2005).

Kata "pengobatan" dapat diartikan sebagai proses, perbuatan, dan cara mengobati,sedangkan kata "alternatif" dapat diartikan sebagai pilihan di antara dua atau beberapa kemungkinan. Dengan demikian,pengobatan alternatif dapat didefinisikan sebagai bentuk pelayanan pengobatan yang menggunakan cara, alat, atau bahan yang tidak termasuk dalam standar pengobatan kedokteran modern (pelayanan kedokteran standar) dan digunakan sebagai alternatif atau pelengkap pengobatan kedokteran modern tersebut. Sementara itu, kata "supranatural" berasal dari kata "supra", yang artinya "atas" dan "nature", yang artinya"alam", sehingga supranatural digunakan untuk menyebutkan kejadian yang tidak dapat dijelaskan dengan hukum alamatau berada di atas dan di luar alam. Oleh karena itu, pengobatan alternatif supranatural adalah pengobatan yang biasanya berkaitan dengan hal gaib dan biasanya mudah menyeret masyarakat awam kepada hal yang bersifat mistis. Pengobatan supranatural sering 
dikaitkan dengan paranormal dan okultisme. Hampir semua paranormal mengatasnamakan agama. Dalam melakukan praktik pengobatannya, tidak jarang paranormal meminta syarat atau imbalan berupa sesajen kepada pasien, misalnya meminta pasien menyembelih ayam putih atau hitam, membawa telur ayam, menaburkan bunga, dan hal-hal aneh lainnya yang disertai berbagai pantangan dan petuah sakral(Syamsudin, 2016).

Pawlikowski et al. (2015) dan Ellens (2008) menggunakan istilah miraculous healing (pengobatan ajaib) yang merujuk ke istilah pengobatan alternatif supranatural. Miraculous healing merupakan pengobatan terhadap suatu penyakit yang mekanisme penyembuhannya berkaitan langsung dengan kekuatan atau keajaiban Tuhan. Tuhan menciptakan alam semesta, sehingga semua fenomena yang ada di dalamnya selalu berkaitan dengan Tuhan. Keajaiban (miracles) dianggap sebagai petunjuk khusus yang diberikan Tuhan kepada manusia. Oleh karena itu, penyebab keajaiban dalam pengobatan supranatural berasal dari luar alam, yaitu dari Tuhan. Bahkan para pemikir modern dan kontemporer juga mempertahankan pemikiran bahwa keajaiban yang terjadi dalam pengobatan supranatural terjadi karena adanya peran Tuhan.

Marwoto \& Rahayu (2010) mengemukakan bahwa sarana dan prasarana pengobatan alternatif supranatural yang dilakukan oleh seorang paranormal atau dukun dengan paranormal lainnya cenderung berbeda. Sarana dan prasarana pengobatan tersebutdi antaranya berupa air putih yang diberi mantra atau doa serta diludahi, air sirih, ramuan tradisional, dupa, kembang, menyan, pusaka, tulisan rajah, darah kera, getah tumbuh-tumbuhan, tusuk jari, dan tenaga dalam. Masing-masing sarana dan prasarana tersebut digunakan oleh paranormal yang berbeda untuk pengobatan penyakit yang berbeda pula.

Salah satu faktor utama yang dianggap menentukan keberhasilan pengobatan alternatif supranatural adalah kekuatan gaib yang dimiliki oleh paranormal. Menurut beberapa paranormal, kekuatan gaib yang berupa tenaga dalam dapat disalurkan ke tubuhpasien melalui pembuluh-pembuluh darah dan akan berfungsi membunuh kuman-kuman penyakit yang ada pada tubuh pasien. Selain itu, semua jenis penyakit pada mulanya berasal dari ketidakseimbangan antara jasmani dan rohani manusia(Marwoto \& Rahayu, 2010).

\section{Gelombang Otak}

Di dalam otak manusia terdapat jutaan sel-sel saraf atau neuron, yang masing-masing menghasilkan tegangan listrik lemah. Agregat dari seluruh tegangan listrik yang dihasilkan dari neuron-neuron di otak tersebut diyakini menghasilkan gelombang yang dikenal sebagai gelombang otak (brainwave). Gelombang otak ini dapat ditangkap dan divisualisasikan dalam bentuk electroencephalograph(EEG). Alat untuk menampilkan gelombang otak dalam bentuk EEGtersebut pertama kali ditemukan oleh seorang psikiater dari Jerman, yaitu Hans Berger (1919 - 1938) pada tahun 1929(Sunardi, Dodi, \& Yuniarti, 2017).Secara umum, EEG diperoleh dengan menggunakan elektroda-elektroda yang ditempatkan di kulit kepala yang telah dilapisi gel yang dapat menghantarkan listrik. Elektroda-elektroda dapat mendeteksi serta mencatat tegangan-tegangan listrik dan kemudian menampilkannya dalam bentuk $E E G$, yang merupakan hasil superposisi dari banyak sinyal atau gelombang sederhana yang dihasilkan oleh masingmasing neuron (NeuroSky, 2009).

EEG biasanya dinyatakan dalam pita frekuensi, dimana perubahan amplitudonya sangat terkait dengan rangsangan eksternal dan kondisi mental (NeuroSky, 2009).Berdasarkan frekuensinya, gelombang otak manusia dibedakan menjadi gelombang gamma, beta, alfa, teta, dan delta. Kelima gelombang otak tersebut dihasilkan secara simultan, tetapi pada keadaan tertentu terdapat gelombang otak yang lebih dominan.Gambar 1 menunjukkan pola gelombang otak untuk lima keadaan mental yang berbeda (NeuroSky, 2009; Sunardi, Dodi, \& Yuniarti, 2017). 


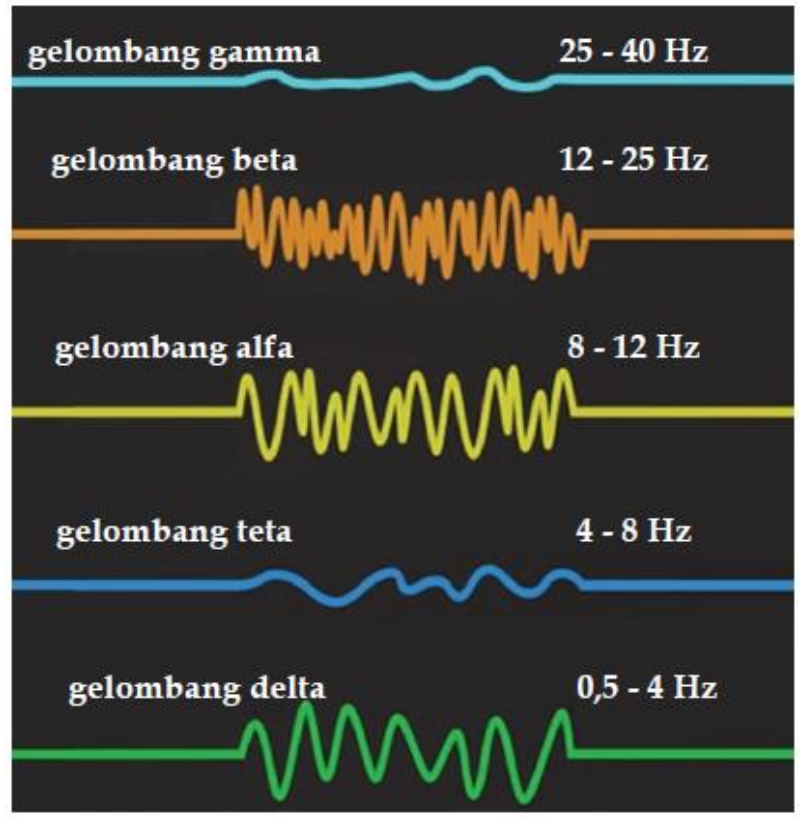

Gambar 1. Jenis-jenis gelombang otak manusia(Sunardi et al., 2017)

Sumber: http://img.theepochtimes.com, diunduh tanggal 30-05-2017, pukul 05.45 WIB.

Gelombang gamma ( $\gamma$ )adalah gelombang otak yang mempunyai frekuensi $25-40 \mathrm{~Hz}$ dan amplitudo 0,5 - 2 mikrovolt. Gelombang ini dipancarkan ketika seseorang melakukan aktivitas mental yang sangat tinggi dan berada dalam kesadaran penuh, misalnya ketika sedang berada dalam keadaan takut, histeris, dan panik berlebihan. Gelombang otak gamma ini berbahaya bagi otak.

Gelombang beta $(\beta)$ adalah gelombang otak yang mempunyai frekuensi $12-25 \mathrm{~Hz}$ dan amplitudo $1-5$ mikrovolt. Gelombang ini dipancarkan ketika seseorang melakukan aktivitas mental yang terjaga penuh, misalnya ketika sedang membaca, berdiskusi, berpikir, konsentrasi, memecahkan masalah. Ketika otak seseorang memancarkan gelombang beta, maka bagian otak yang bekerja secara dominan adalah otak kiri. Pada keadaan ini, otak memproduksi hormon kortisol dan norepinefrin yang berperan pada timbulnya rasa cemas, khawatir, stress, dan marah.

Gelombang alfa $(\alpha)$ adalah gelombang otak yang mempunyai frekuensi $8-12 \mathrm{~Hz}$ dan amplitudo 20 - 80 mikrovolt. Gelombang ini dipancarkan ketika seseorang berada dalam keadaan rileks, mengantuk, melamun, atau berimajinasi. Pada gelombang alfa, otak manusia memproduksi hormon serotonin dan endorfin yang menyebabkan seseorang merasa tenang, nyaman, dan bahagia. Gelombang alfa juga dapat meningkatkan kekebalan tubuh, menyebabkan pembuluh darah terbuka lebar, membuat detak jantung stabil, dan meningkatkan kemampuan indera. Otak anak balita cenderung dominan memancarkan gelombang alfa, sehingga anak balita lebih mudah dan cepat menyerap semua informasi yang diperoleh dari luar. Dalam konteks hipnosis, ketika otak memancarkan gelombang alfa, maka filter menuju ke area pikiran bawah sadar seseorang mulai terbuka, sehingga mulai mudah menerima sugesti.

Gelombang teta $(\theta)$ adalah gelombang otak yang mempunyai frekuensi $4-8 \mathrm{~Hz}$ dan amplitudo 5 - 10 mikrovolt. Gelombang ini dipancarkan ketika seseorang berada dalam keadaan trance, tidur hipnosis, meditasi dalam, dan khusyu. Ketika otak seseorang memancarkan gelombang teta, maka orang tersebut memasuki area pikiran bawah sadarnya, sehingga sugesti yang diberikan orang lain akan mudah diterima. Dalam kondisi ini, otak manusia memproduksi hormon melatonin, catecholamine, dan arginine vasopressin (AVP) yang menyebabkan pikiran menjadi lebih khusyu, rileks, tenang, hening, dan berpotensi memunculkan intuisi.

Gelombang delta ( $\delta$ )adalah gelombang otak yang mempunyai frekuensi $0,5-4 \mathrm{~Hz}$ dan amplitudo $100-200$ mikrovolt. Gelombang ini dipancarkan ketika seseorang berada dalam keadaan tidur lelap tanpa mimpi. Pada keadaan ini tubuh dan pikiran manusia sedang berada dalam keadaan istirahat. Tubuh melakukan proses pemulihan dan perbaikan terhadap jaringan yang mengalami kerusakan dan memproduksi sel-sel baru. Ketika otak memancarkan 
gelombang delta, otak memproduksi hormon pertumbuhan $\mathrm{HGH}$ (human growth hormone) yang membuat seseorang lebih awet muda.

\section{Hipnosis dan Hipnoterapi}

Istilah hipnosis berasal dari kata "Hypnos", yaitu nama Dewa Tidur dalam Mitologi Yunani. Istilah ini pertama kali diperkenalkan pada tahun 1842 oleh seorang dokter berkebangsaan Skotlandia, James Braid (1795 - 1860). Menurut James Braid, seseorang yang berada dalam keadaan hipnosis, sistem sarafnya berada dalam keadaan tidur. Meskipun kemudian diketahui bahwa keadaan hipnosis ternyata berbeda dengan keadaan tidur alamiah (tidur istirahat)(Martin \& Bobgan, 2001).

Menurut Sunardi, Dodi, \& Yuniarti (2017), hipnosis didefinisikan secara beragam dan tergantung konteks, yaitu hipnosis dapat didefinisikan sebagai suatu keadaan atau kondisi, teknik atau kegiatan, dan pengetahuan. Sebagai keadaan, hipnosis adalah suatu keadaan dimana perhatian seseorang menjadi sangat terpusat, sehingga sugestivitas (tingkat penerimaan saran atau sugesti) orang tersebut menjadi sangat tinggi. Hipnosis juga didefinisikan sebagai suatu keadaan dimana kesadaran seseorang berubah dan ditandai dengan mudahnya orang tersebut dalam menerima sugesti. Sebagai teknik atau kegiatan, hipnosis adalah teknik komunikasi untuk mempengaruhi seseorang, sehingga tingkat kesadaran orang tersebut berubah, yaitu dengan cara menurunkan frekuensi gelombang otak dari frekuensi beta menjadi frekuensi alfa dan teta. Hipnosis juga didefinisikan sebagai teknik atau kegiatan mempengaruhi orang lain untuk masuk ke dalam kondisi hipnosis (hypnotic trance) atau teknik komunikasi untuk mengeksplorasi pikiran bawah sadar (subconscious mind) seseorang.

Meskipun hipnosis didefinisikan secara beragam, tetapi definisi hipnosis yang banyak digunakan adalah definisi yang dibuat oleh U.S. Department of Education, Human Services Division, yaitu "Hipnosis adalah penembusan (bypass) faktor kritis dari pikiran sadar (conscious mind) yang diikuti dengan diterimanya sugesti atau pemikiran tertentu oleh pikiran bawah sadar" (Sunardi, Dodi, \& Yuniarti, 2017).

Jauh sebelum orang mengenal kata hipnosis, kegiatan hipnosis, terutama untuk penyembuhan telah dipraktikkan dalam bentuk ritual-ritual yang dipercaya dapat memberikan kesembuhan bagi pasien. Sebagai contoh, para pemuka agama bangsa Mesir Kuno pada tahun 1552 SM telah mempraktikkan "pengobatan hipnosis" dengan cara menempelkan tangan di kepala pasien sambil mengucapkan kalimat-kalimat sugesti, sehingga pasien yang percaya dengan kalimat-kalimat sugesti tersebut dapat sembuh dari penyakitnya. Pada awalnya praktikpraktik hipnosis sangat lekat dengan budaya dan upacara-upacara keagamaan yang dipercaya berhubungan dengan kekuatan gaib dan mistis (Sunardi, Dodi, \& Yuniarti, 2017).

Pengetahuan tentang hipnosis modern dipelopori oleh seorang dokter berkebangsaan Austria, Franz Anton Mesmer (1734 - 1815). Menurut Mesmer, dalam tubuh manusia terdapat kekuatan magnetik dan cairan universal yang berfungsi untuk menjaga keseimbangan tubuh. Jika aliran cairan universal dalam tubuh seseorang mengalami gangguan, maka orang tersebut juga dapat mengalami gangguan kesehatan mental dan fisik.Mesmer juga mengklaim bahwa dia mempunyai kekuatan magnetik yang mampu menghilangkan sumbatan dan memperlancar aliran cairan universal dalam tubuh manusia. Dalam melakukan terapi terhadap pasien, Mesmer mengisi penuh sebuah bak dengan air dan kemudian memasukkan besi magnet ke dalamnya. Pasien yang akan diobati diminta untuk memegang besi magnet itu dengan harapan akan mengalir energi dari magnet ke tubuh pasien dan energi tersebut diyakini dapat melancarkan aliran cairan universal yang tersumbat. Mesmer kemudian melakukan teknik penyembuhan dengan menggunakan kalimat-kalimat sugesti yang dapat membuat pasien masuk dalam kondisi trance dan menerima sugesti-sugesti penyembuhan yang diberikannya. Teknik penyembuhan yang dipraktikkan oleh Mesmer di atas dikenal sebagai "animal magnetism" atau lebih populer dikenal sebagai "mesmerism"(Martin \& Bobgan, 2001).

Teori animal magnetism atau mesmerism yang diajukan Franz Anton Mesmer mengundang rasa ingin tahu banyak ahli. Seorang dokter Skotlandia yang berpraktik di kota Manchester, Inggris, James Braid (1795 - 1860) menguji teori animal magnetism atau mesmerism. Berdasarkan pengujian yang ia dilakukannya, Braid menemukan bahwa kondisi trance pada teknik penyembuhan Mesmer tidak ada hubungannya sama sekali dengan animal magnetism, tetapi murni reaksi dari suatu kekuatan sugesti. Lebih lanjut Braid menjelaskan bahwa fenomena yang dialami pasien dalam proses mesmerism adalah fenomena tidurnya saraf (nervous sleep) dan Braid menyebut fenomena tersebut sebagai neuro-hypnotism atau 
singkatnya dapat disebut sebagai hipnotisme saja. James Braid kemudian mempublikasikan hasil pengujiannya terhadap teori Mesmer dalam bukunya yang berjudul "Neurypnology or The Rationale of Nervous Sleep Considered In Relation With Animal Magnetism" pada tahun 1843 (Sunardi, Dodi, \& Yuniarti, 2017).

Setelah berhasil melakukan pengujian terhadap teori Mesmer, James Braid bekerja sama dengan Profesor William Benjamin Carpenter (seorang neuro-psikolog) yang memperkenalkan teori sugesti ideo-motor reflex. Pada tahun 1847, Braid kemudian menemukan bahwa semua fenomena utama hipnotisme seperti katalepsi, anestesi, dan amnesia dapat diinduksi tanpa tidur, sehingga kata hipnotisme menjadi kurang tepat untuk menyatakan fenomena trance Mesmer. Menurut Braid, kata yang tepat untuk menyatakan fenomena trance tersebut adalah monodeism, yang berarti konsentrasi atau fokus pada satu ide atau gagasan. Akan tetapi, istilah hipnotisme dan hipnosis telah terlanjur populer, sehingga James Braid kemudian dikenal sebagai Bapak Hipnosis Modern (The Father of Modern Hypnosis).

Seiring dengan perkembangan ilmu pengetahuan, praktik-praktik hipnosis kemudian dapat dijelaskan secara lebih ilmiah dan rasional, sehingga kesan mistis hipnosis perlahan hilang dan bahkan hipnosis lahir sebagai salah satu pengetahuan modern yang diaplikasikan secara luas dalam berbagai bidang. James Esdaile (1808 - 1859) mencatat ratusan proses pembedahan atau operasi besar dengan hipnosis sebagai anestesi. John Elliotson (1791 1868) mendirikan rumah sakit hipnosis pertama, yang terkenal dengan proses pembedahan atau operasi tanpa rasa sakit. Elliotson juga menerbitkan Zoist, yaitu jurnal medis pertama tentang perawatan medis menggunakan hipnosis.Selain digunakan dalam proses pembedahan atau operasi, hipnosis juga diaplikasikan dalam kedokteran gigiuntuk membantu pasien mengurangi rasa cemas, stress, dan rasa takut, serta untuk anestesi dalam proses perawatan atau tindakan tertentu, sehingga dapat mengurangi penggunaan peralatan dan obat-obatan medis.

\section{Hubungan Gelombang Otak, Pikiran, dan Hipnosis}

Menurut Sunardi, Dodi, \& Yuniarti (2017), gelombang otak manusia dapat berubah dari satu pola pita frekuensi ke pola pita frekuensi lainnya. Perubahan pola gelombang otak ini dapat dipengaruhi oleh kondisi mental atau pikiran seseorang. Ketika seorang hipnotis (operator hipnosis) menghipnosis seseorang, maka yang dilakukannya adalah menurunkan frekuensi gelombang otak (brainwave) dari frekuensi gelombang beta (keadaan normal) ke frekuensi gelombang alfa-teta (keadaan hipnosis), sehingga subjek atau suyet (orang yang diberi perlakuan hipnosis), yang tadinya mempunyai banyak fokus hanya terfokus pada satu hal saja. Proses penurunan gelombang otak ini dilakukan dengan teknik komunikasi hipnotik yang bersifat persuasif.

\begin{tabular}{|c|c|c|c|}
\hline Keadaan Normal & \multicolumn{2}{|c|}{ Keadaan Hipnosis } & Keadaan Tidur \\
\hline $5-9$ Fokus & \multicolumn{2}{|c|}{1 Fokus } & 0 Fokus \\
\hline \multirow[t]{2}{*}{ Gelombang Beta } & Gelombang Alfa & Gelombang Teta & Gelombang Delta \\
\hline & \multicolumn{2}{|c|}{ Subconscious Mind } & \\
\hline \multicolumn{4}{|c|}{ Filter Pikiran atau Reticular Activating System (RAS) semakin terbuka } \\
\hline \multicolumn{4}{|l|}{ Conscious Mind } \\
\hline Non Sugestif & \multicolumn{2}{|c|}{ Sugestif \& Sangat Sugestif } & Non Sugestif \\
\hline
\end{tabular}

Gambar 2. Penurunan gelombang otak akibat proses hipnosis(Sunardi et al., 2017)

Menurut IBH (2015), perubahan gelombang otak manusiaterkait dengan keadaan pikiran. Pikiran manusia ini dimodelkan sebagai suatu area kesadaran yang terbagi ke dalam dua bagian utama, yaitu area pikiran sadar (conscious mind), yang merupakan area non-hipnotik dan area pikiran bawah sadar (subconscious mind), yang merupakan area hipnotik. Pikiran sadar adalah proses mental yang disadari dan dapat dikendalikan. Pikiran ini bersifat kritis, analitis, logis, dan rasional. Kontribusi pikiran sadar ini terhadap kepribadian, perilaku, 
kebiasaan, cara berpikir, dan kondisi mental seseorang relatif kecil, yaitu hanya sekitar 10 $12 \%$. Sementara itu, pikiran bawah sadar adalah proses mental yang terjadi secara otomatis. Pikiran bawah sadar bersifat kurang kritis atau bahkan cenderung netral. Pemodelan kesadaran manusia dianalogikan seperti gunung es di lautan, dimana hanya sebagian kecil saja yang terlihat di permukaan, sedangkan bagian terbesar justru tidak terlihat di bawah permukaan.

Kontribusi pikiran bawah sadar terhadap kepribadian, perilaku, kebiasaan, cara berpikir, dan kondisi mental seseorang jauh lebih besar dibandingkan dengan pikiran sadar, yaitu sekitar 88 - 90 \%.Pikiran sadar dan pikiran bawah sadar manusia bekerja secara bersamaan dan saling mempengaruhi satu sama lain. Pikiran sadar bekerja untuk mengidentifikasi informasi dari dunia luar, kemudian membandingkan informasi tersebut dengan data yang sudah tersimpan di dalam memori, menganalisa, dan memutuskan untuk membiarkan sementara, menyimpan, atau membuang informasi baru tersebut. Sementara itu, pikiran bawah sadar bekerja menyimpan semua memori jangka panjang, pengalaman, pengetahuan, emosi, kebiasaan, kepribadian, intuisi, kreativitas, persepsi, keyakinan atau kepercayaan, dan sistem nilai. Pikiran bawah sadar juga berperan mengatur fungsi kerja semua organ tubuh dan mengendalikan aktivitas-aktivitas tubuh seperti berkedip, bernapas, dan bahkan bermimpi(IBH, 2015).

Area pikiran bawah sadar (subconscious mind) dilindungi oleh suatu penyaring (filter) yang dikenal dengan istilah daerah kritis (critical area). Jika filter ini terbuka lebar, informasi akan masuk ke area bawa sadar dengan mudah, tetapi jika filter tertutup rapat, informasi tidak akan masuk ke area bawah sadar. Demikian juga jika filter terbuka sebagian, akan ada sebagian informasi yang masuk ke area bawah sadar. Informasi yang dimaksud dalam hal ini adalah segala hal yang masuk melalui modalitas utama manusia (panca indera atau VAKOG), yaitu melalui mekanisme visual (penglihatan), auditori (pendengaran), kinestetik (sentuhan atau gerakan), olfaktori (penciuman), dan gustatori (pengecapan)(IBH, 2015).

Langkah awal yang harus dilakukan seorang hipnotis untuk melakukan proses hipnosis formal adalah dengan menonaktifkan atau setidaknya mengurangi keaktifan pikiran sadar. Dengan tidak aktif atau berkurangnya keaktifan pikiran sadar, maka filter pikiran tidak lagi terjaga dengan baik, sehingga dapat dilakukan komunikasi dan intervensi secara langsung dengan pikiran bawah sadar. Adapun salah satu cara menonaktifkan pikiran sadar tersebut adalah dengan membuat pikiran ini menjadi sangat rileks atau lebih baik lagi jika pikiran sadar ini dibuat tertidur. Dalam hal ini, tidur hipnosis berbeda dengan tidur istirahat. Pada keadaan tidur hipnosis, hanya bagian pikiran sadar saja yang tidak aktif, sedangkan bagian pikiran bawah sadarnya tetap aktif dan terjaga. Sementara itu, pada keadaan tidur istirahat, bagian pikiran sadar maupun bagian pikiran bawah sadar tidak lagi aktif (Sunardi, Dodi, \& Yuniarti, 2017).

Menurut IBH (2015), dalam melakukan proses hipnosis, maka otoritas menjadi penting. Dengan otoritas yang dimilikinya, seseorang menjadi sangat mudah untuk memasuki alam bawah sadar orang lain. Dalam hal ini, motivator, penceramah agama, guru, dosen, artis, aktor, atlet, polisi, tentara, dan figur-figur tertentu mempunyai otoritas yang telah melekat kuat dengan profesinya, sehingga mereka dapat lebih mudah menerapkan hipnosis alamiah atau bahkan hipnosis formal sekalipun.

\section{Hubungan Pengobatan Supranatural dan Hipnosis}

Sesuai dengan karakteristiknya, prosedur pengobatan supranatural yang dilakukan oleh seorang dukun atau paranormal tidak dapat dibuktikan secara ilmiah sebagaimana proses penyembuhan medis. Sifat dan prosedur seperti laku spiritual semata-mata merupakan proses penyatuan antara energi bawah sadar yang dimiliki oleh paranormal untuk dipertemukan pada kekuatan-kekuatan gaib yang membantunya pada proses penyembuhan seorang pasien. Bisa jadi, tidak seluruh proses penyembuhan yang dilakukan oleh dukun berhasil (Marwoto \& Rahayu, 2010).

Paranormal menjelaskan mekanisme penyembuhan penyakit dari proses pengobatan yang dilakukannya dengan menggunakan konsep-konsep mistis. Dalam konsep ini, setiap manusia mempunyai "roh penjaga". Roh tersebut cenderung suci dan selalu mengontrol kekuatan-kekuatan luar yang akan menyerang seseorang. Akan tetapi, jika seseorang berbuat tidak baik dan tidak dapat dikontrol lagi, maka "roh penjaga" tersebut juga akan marah. Ketika ada kekuatan dari luar menyerang, maka "roh penjaga" tidak mau lagi membela. Dalam kondisi seperti itulah penyakit akan menyerang manusia. Dengan kekuatan gaib yang dimilikinya,paranormal dapat berkomunikasi atau melakukan kontak batin dengan "roh penjaga" sehingga dapat memberikan efek penyembuhan dari penyakit yang diderita pasien. 
Praktik pengobatan supranatural yang dilakukan oleh paranormal dapat dipandang sebagai praktik hipnosis. Hal ini karena dengan status paranormal yang dianggap sebagai orang sakti yang menguasai alam lain dan mempunyai kekuatan gaib, maka dengan sendirinya paranormal mempunyai otoritas alamiah yang menjadi modal dasar untuk dengan mudah menggeser kesadaran seseorang menuju ke area hipnotik dengan menggunakan komunikasi hipnotik, yang dapat berupa komunikasi yang bersifat otoriter (authoritarian) atau komunikasi yang bersifat ajakan dan kerjasama (permissive \& cooperative).

Ketika seorang paranormal melakukan praktik pengobatan supranatural, seorang pasien dapat mengalami kondisi hipnotik tertentu, sehingga sangat sugestif dengan kalimat-kalimat atau perlakuan-perlakuan tertentu, yang kemudian dapat merasakan dampak kesembuhan layaknya kesembuhan yang diperoleh melalui pengobatan dengan metode hipnosis atau hipnoterapi. Menurut Erickson dan Rossi (dalam Sunardi, Dodi, \& Yuniarti, 2017), hipnoterapi adalah proses untuk membantu seseorang menggunakan mental, asosiasi, memori, potensipotensi yang dimilikinya untuk mencapai tujuan-tujuan penyembuhan tertentu dengan bantuan sugesti-sugesti hipnosis.

Sebagaimana penyembuhan medis, masalah keberhasilan pengobatan supranatural sangat bergantung banyak hal, misalnya keyakinan, tingkat kegawatan penyakit, dan ramuan atau obat yang dikonsumsi(Marwoto \& Rahayu, 2010). Dalam konteks hipnosis, faktor keyakinan sangat berpengaruh pada tingkat kedalaman trance pasien. Semakin dalam keadaan trance seorang pasien ketika dilakukan proses pengobatan hipnosis, semakin baik dampak penyembuhan yang dihasilkan. Gambar 3 menunjukkan skala Davis Husband untuk mengukur kedalaman trance seseorang ketika dilakukan proses penyembuhan dengan metode hipnosis atau hipnoterapi.

\section{SKALA DAVIS HUSBAND (KEDALAMAN TRANCE)}

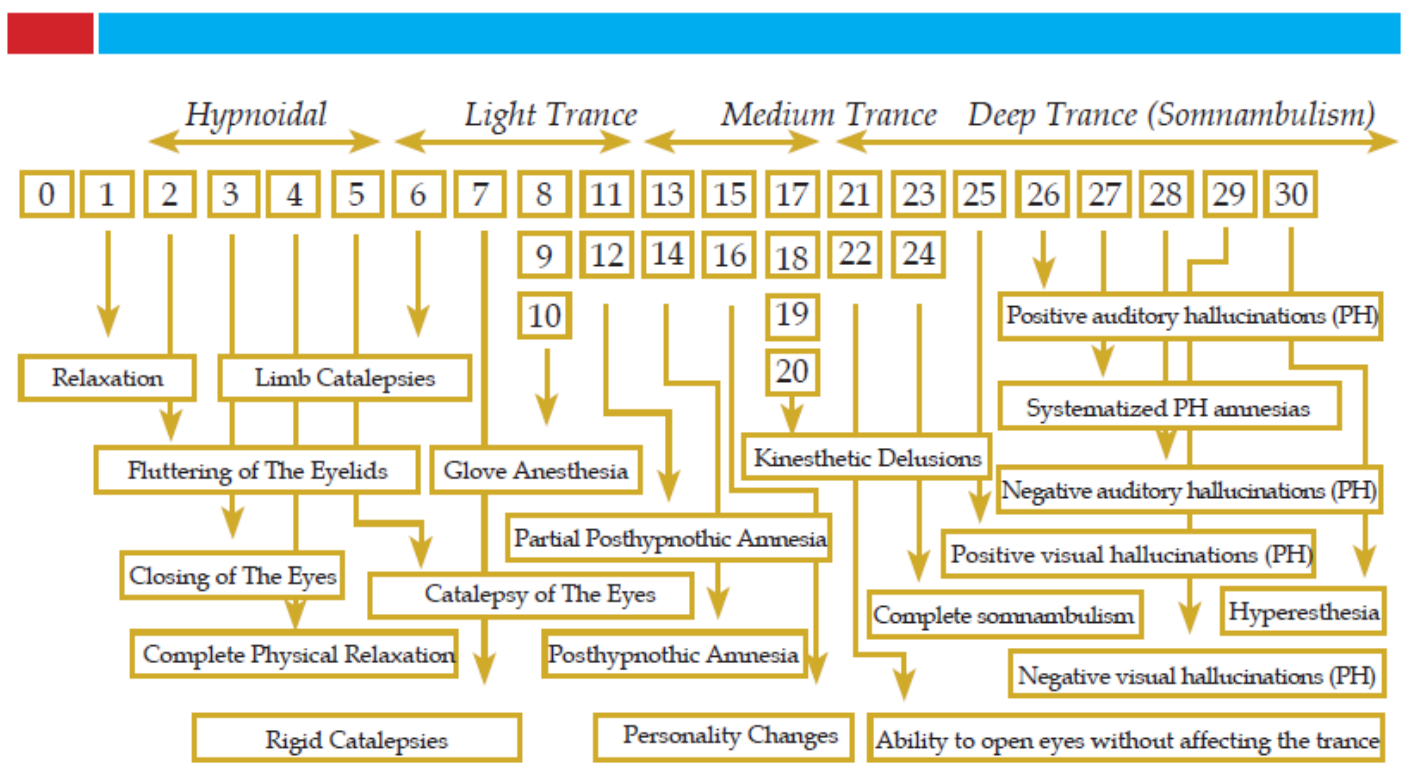

${ }^{*} \mathrm{PH}=$ Post Hypnotic

Gambar 3. Skala Davis husband(IBH, 2015)

Kedalaman trance berdasarkan skala Davis Husband pada Gambar 3 dapat diurutkan sebagai berikut: 1) Kondisi kesadaran normal, 2) Kondisi hipnoidal (hypnoidal state). Kondisi ini di antaranya ditandai dengan tubuh rileks, kelopak mata bergetar atau berkedip cepat, mata mulai tertutup, relaksasi tubuh sempurna, dan katalepsi beberapa anggota tubuh, 3) Kondisi hipnosis ringan (light trance). Kondisi ini di antaranya ditandai dengan katalepsi mata, tungkai, dan badan serta hilangnya rasa di beberapa bagian tubuh (glove anesthesia), 4) Kondisi hipnosis sedang (medium trance). Kondisi ini di antaranya ditandai dengan amnesia parsial dan perubahan karakter (personality changes), dan 5) Kondisi hipnosis dalam (deep trance) atau somnambulism. Kondisi ini di antaranya ditandai dengan halusinasi positif (seolah-olah melihat sesuatu atau mendengar suara tertentu), halusinasi negatif (tidak dapat melihat sesuatu dan mendengar suara yang sebenarnya ada), amnesia sistematis, dan amnesia total. Proses 
hipnoterapi hendaknya dilakukan pada keadaan ini. Karena pada keadaan ini, keadaan subjek menjadi sangat sugestif.

\section{Pandangan Filsafat terhadap Pengobatan Supranatural dan Hipnosis}

Ekplanasi pengobatan alternatif supranatural yang ditinjau berdasarkan teori gelombang otak dan hipnosis dapat dikatakan sebagai eksplanasi analogis. Menurut Firman (2018), eksplanasi analogis adalah eksplanasi yang menjelaskan fenomena dengan membandingkan fenomena tersebut pada fenomena pembanding yang lebih dikenal atau lebih konkrit. Dalam hal ini, pengobatan alternatif supranatural merupakan eksplanandum yang bersifat kompleks dan kurang dikenal, sedangkan pengobatan dengan metode hipnosis atau hipnoterapi merupakan eksplanan yang lebih dikenal dan mempunyai langkah-langkah pengobatan yang lebih jelas.

Ahli pengobatan supranatural adalah dukun atau paranormal yang dianggap mempunyai kekuatan gaib dan mampu berkomunikasi dengan alam lain. Anggapan ini menjadikan seorang paranormal mempunyai otoritas yang kuat terhadap pasien, sehingga dengan pola komunikasi tertentu, pasien dapat dengan mudah memasuki alam bawah sadar dan sangat sugestif dengan komunikasi-komunikasi atau perlakuan-perlakuan penyembuhan. Hal ini analog dengan pengobatan dengan metode hipnosis atau hipnoterapi, dimana hipnoterapis dengan bermodal otoritas dan kemampuan komunikasinya dapat menggiring pasien ke level trance tertentu, sehingga sugesti-sugesti penyembuhan yang diberikan kepada pasien dapat memberikan penyembuhan pada batas-batas tertentu.

Mekanisme penyembuhan penyakit dengan pengobatan supranatural tidak dapat dijelaskan secara rinci dan ilmiah. Hal ini karena paranormal menggunakan alibi-alibi yang bersifat mistis dan gaib untuk memberikan keyakinan kepada pasien. Sementara itu, pengobatan dengan metode hipnosis atau hipnoterapi mempunyai langkah-langkah yang jelas terstruktur, yaitu pre induction talk, induction, deepening, depth level test, therapeutic suggestion, dan induction (IBH, 2015).

Landasan ekplanasi pengobatan alternatif supranatural yang selama ini berkembang adalah tahayul (superstition). Menurut Firman (2018), tahayul seringkali menjadi landasan terhadap fenomena alam yang diyakini oleh masyarakat awam, termasuk di dalamnya penjelasan terhadap wabah penyakit. Sementara itu, memandang pengobatan supranatural sebagai proses hipnosis dapat menjadikan pengobatan supranatural lebih rasional. Hal ini karena pengetahuan hipnotis berkembang mengikuti pola eksplanasi ilmiah model HempelOppenheim atau model deduktif-nomologis (model D-N). Firman (2018) mengemukakan bahwa terdapattiga kondisi logis yang menjadi syarat eksplanasi ilmiah model D-N, yaitu eksplananeksplanan harus secara deduktifmengarah pada eksplanandum (eksplanandum diturunkan dari eksplanan-eksplanan; deduksi harus menggunakan hukum umum;dan eksplanan-eksplanan harus mempunyai konten empiris.

Deduksi ilmiah hipnosis mengarah pada struktur dan fungsi otak yang terintegrasi dalam konsep-konsep fisika, biologi, dan kimia. Dalam hal ini, kondisi neuron-neuron di otak manusia yang secara biologi berjumlah sangat banyak dapat mengalami proses-proses kelistrikan yang terkait dengan transmisi impuls saraf. Proses-proses kelistrikan tersebut menghasilkan gelombang otak tertentu yang memungkinkan seseorang berada pada kondisi hipnosis yang sangat sugestif, dimana hal ini dipengaruhi oleh kondisi mental atau pikiran. Secara logis, kajian biokimia juga menjelaskan bahwa kondisi mental seseorang berpengaruh pada sistem hormon yang mengatur proses-proses fisis dan fisiologi yang terjadi dalam otak manusia.

Hasil-hasil penelitian empiris menunjukkan pemanfaatan hipnosis dalam kehidupan sehari-hari, misalnya untuk pengobatan hipnoterapi yang secara sukses dapat menyelesaikan: (1) masalah-masalah yang berkaitan dengan motivasi dan pemberdayaan diri, 2) masalahmasalah mental dan emosional, misalnya stress, depresi, kecemasan, kebiasaan buruk, perilaku buruk, dan insomnia, dan (3) penyakit-penyakit fisik yang bersumber dari gangguan psikologis (psychosomatic ilness). Penyakit-penyakit seperti eksim, hipertensi, radang perut, gangguan jantung, psoriasis, dan sakit pinggang bagian bawah merupakan contoh penyakit psikosomatik karena dianggap sangat rentan dengan faktor psikologis seperti stress dan cemas. Hasil-hasil penelitian tersebut memperkuat kebenaran hipnosisyang memberikan nilai manfaat terhadap manusia. Oleh karena itu, hipnosis menjadi ilmu yang memenuhi teori kebenaran pragmatisme. Menurut Firman (2018), kebenaran pragmatisme adalah suatu kebenaran yang diterima berdasarkan sifat fungsionalnya dalam kehidupan praktis. 


\section{Kesimpulan}

Pengobatan supranatural adalah pengobatan yang biasanya berkaitan dengan hal gaib dan mistis. Pengobatan supranatural sering dikaitkan dengan paranormal dan okultisme, dimana proses penyembuhan penyakit dengan metode ini tidak dapat dijelaskan secara ilmiah. Metode pengobatan supranatural dapat dipandang sebagai pengobatan dengan metode hipnosis, dimana kesembuhan pasien ditentukan oleh kemampuan paranormal untuk mengeksplorasi pikiran bawah sadar dan kemampuan paranormal untuk membawa pasien menuju ke kondisi hipnosis tertentu, sehingga pasien dapat menerima sugesti-sugesti penyembuhan tertentu.

Penjelasan pengobatan supranatural sebagai pengobatan dengan metode hipnosis menjadikan mekanisme pengobatan supranatural dapat dijelaskan secara lebih rasional dan memenuhi kriteria eksplanasi deduktif-nomologis (model D-N). Hal ini karena pengetahuan hipnosis dapat dijelaskan secara deduktif melalui konsep-konsep fisika, kimia, dan biologi. Selain itu, bukti-bukti empiris pemanfaatan hipnosis dalam kehidupan sehari-hari menjadikan hipnosis memenuhi teori kebenaran pragmatisme.

\section{Daftar Pustaka}

Ellens, H. (2008). Miracles: God, Science, and Psychology in The Paranormal. (1, Ed.). United States of America The: Greenwood Press. Retrieved from www.greenwood.com

Fanani, Syaikhul, Triana Kesuma Dewi. (2014). Health Belief Model Pada Pasien Pengobatan Alternatif Supranatural Dengan Bantuan Dukun. http://journal.unair.ac.id. Diakses 9 Mei 2019.

Firman, H. (2018). Pengantar Filsafat Ilmu Pengetahuan Alam. Bandung: Program Studi Pendidikan IPA, Sekolah Pascasarjana, Universitas Pendidikan Indonesia.

Hidayatullah, R. (2010). Tinjauan Hadis Terhadap Praktek Paranormal (Studi Kasus Praktek Ustadz Mohammad Thoha). Fakultas Ushuluddin Dan Filsafat Universitas Islam Negeri Syarif Hidayatullah.

IBH. (2015). Basic Hypnotherapy: Certified Hypnotist (CH) Student Manual. Jakarta: The Indonesian Board of Hypnotherapy.

Martin, \& Bobgan, D. (2001). Hypnosis: Medical, Scientific, or Ocultic? Santa Barbara, California: EastGate Publishers.

Marwoto, \& Rahayu, S. S. (2010). Mekanisme Pengobatan Tradisional Yang Dilakukan DukunDukun Using Di Banyuwangi. DIPA Universitas Jember, (0106).

Muhammad, N. (2011). Gelombang Otak Manusia. Jogjakarta: Diva Press. Diakses 9 Mei 2019

NeuroSky. (2009). Brain Wave Signal (EEG) of Neurosky. NeuroSky Inc.

Nurul Fatma, Andi. dkk. 2017. Pengaruh Pengondisian Gelombang Otak Zona Alfa Pada Apersepsi Pembelajaran Terhadap Motivasi Belajar Biologi Siswa Kelas Xi Ipa Man 3 Makassar. http://journal.uin-alauddin.ac.id/index.php. Diakses 9 Mei 2019.

Pawlikowski, J., Wiechetek, M., Sak, J., \& Marek, J. (2015). Beliefs in Miraculous Healings, Religiosity and Meaning in Life. Religions, 6, 1113-1124. https://doi.org/10.3390/rel6031113

Prasetya, P. W. (2005). Pasien dan Paranormal. Fakultas Psikologi Universitas Surabaya, 2005.

Sunardi, Dodi, \& Yuniarti, A. (2017). Mind Miracle: Eksplorasi Potensi Otak Melalui Hipnosis (1st ed.). Bandung: Suma Cipta Sarana. 
Jurnal Filsafat Indonesia, Vol. 2 No. 12019

ISSN: E-ISSN 2620-7982, P-ISSN: 2620-7990

Syamsudin. (2016). Pengobatan Alternatif Supranatural Menurut Hukum Islam. Alqalam, 33(2), 110-121.

Syamsuddin. (2016). Pengobatan Alternatif Supranatural Menurut Hukum Islam. http://jurnal.uinbanten.ac.id/index.php/alqalam/article/download/395/353/. Diakses 9 Mei 2019. 